Pomáhajúce profesie, roč. 2, č. 2 2019, 30-39

\title{
VŠíMAVOSŤ A AUTENTICITA U ADOLESCENTOV
}

\author{
Miriama Hudáková, Kristína Együdová \\ Ústav aplikovanej psychológie FSVaZ UKF Nitra \\ mhudakova2@ukf.sk
}

\begin{abstract}
Abstrakt: Ciel'om štúdie bolo skúmanie vzt’ahu medzi všímavost'ou a autenticitou u adolescentov. Výskumný súbor pozostával zo 104 participantov (67 dievčat, 37 chlapcov) s priemerným vekom $\mathrm{M}_{\mathrm{vek}}=17,4 \quad\left(\mathrm{SD}_{\mathrm{vek}}=2,16\right)$. Boli použité nasledujúce dotazníky: Five-Facet Mindfulness Questionnaire - FFMQ (Baer et al., 2006) a Škála kongruencie (Lee, 2002). Výsledky poukazujú na stredne silné pozitívne vzt'ahy medzi globálnou všímavost’ou a autenticitou (ako aj jej jednotlivými dimenziami). Zistili sme tiež slabé pozitívne vzt'ahy medzi aspektmi všímavosti a autenticitou.
\end{abstract}

Kl'účové slová: všímavost', autenticita, adolescenti

\section{1 Úvod}

Všímavost' a jej prínosy sú v súčasnosti predmetom intenzívneho psychologického skúmania. Možno sa zamerat' na jej pozitívne vplyvy pri terapii chronickej bolesti, porúch nálady a pri redukcii stresu. Výskumný záujem tiež vzbudila aj prostredníctvom svojho pozitívneho vplyvu na životnú spokojnost' a medzil'udské vzt'ahy. Autenticita bola donedávna zanedbávanou témou z pohl'adu empirickej psychológie (Sheldon, 2004), súčasné hnutie pozitívnej psychológie (Linley et al., 2006) však začalo podporovat' obnovu záujmu o autenticitu. V príspevku sa venujeme obom zmieneným premenným, všímavosti aj autenticite, medzi ktorými je možné vidiet' prepojenie prostredníctvom teoretického vymedzenia premenných, ktoré môže naznačovat' ich vzájomný prienik, a tiež prepojenie empirické (napr. Kernis a Goldmann, 2006). Ciel'om štúdie je skúmat' vzt’ah všímavosti a jej faktorov $\mathrm{k}$ autenticite $\mathrm{u}$ adolescentov.

\subsection{Všímavost'}

Všímavost' (alebo mindfulness v zahraničnej literatúre, možno sa stretnút' aj s prekladom bdelá pozornost') je pojem, ktorý pochádza $\mathrm{z}$ budhizmu, no našiel si svoje miesto aj $\mathrm{v}$ súčasnej psychológii (Jurkovič, 20015). Aj ked’ sa koncept všímavosti zrodil v budhistickej psychológii, jeho tradícia je omnoho globálnejšia. Príbuzné konštrukty sa objavili v gréckej filozofii, či v koncepciách západoeurópskych, ako aj amerických myslitel’ov, ktoré sa stali súčast'ou fenomenologických, existenciálnych, naturalistických, transcendentálnych a humanistických prístupov (Brown et al., 2007). V súčasnosti neexistuje jednotná definícia všímavosti. Niektorí autori ju chápu ako situačnú charakteristiku alebo vlastnost' vedomia, iní ako dispozíciu, či už v zmysle osobnostnej črty alebo schopnosti, d’alší ako špecifický stav bytia, resp. spôsob spracúvania obsahov prežívania (Látalová, Pilárik, 2014). Kabat-Zinn (2003) definuje všímavost' ako uvedomovanie si, ktoré vyvstáva z úmyselného sústredenia pozornosti v prítomnom okamihu a bez posudzovania odhal'ujúcej sa skúsenosti prebiehajúcej okamih za okamihom. Podl'a Bendu (2007) je všímavost' prirodzená schopnost' byt' duchom teraz a tu - nezaujato registrovat' prežívané psychické a telesné fenomény v prítomnosti. Definícia Browna a Ryana (2003, s. 822) popisuje všímavost' ako "stav receptívnej pozornosti a uvedomovania si práve prítomných udalostí a zážitkov". Penman a Vidyamala (2016) označujú všímavost' za pozorovanie bez kritizovania a so súcitom k sebe. Podstatu všímavosti vidia v schopnosti zachytit' negatívne myšlienky ešte skôr, než nás premôžu. Väčšina definícií všímavosti sa zameriava na jej dve klúčové zložky - pozornost' a akceptáciu (Koróniová, 2016). Práve vedomé zameranie pozornosti umožňuje úmyselné sledovanie myšlienok, pocitov, fyzických vnemov a 
iných stimulov pôsobiacich v prítomnom okamihu. Zložka založená na akceptácii zahŕňa schopnost' zachovat' si otvorený a vnímavý postoj voči týmto zážitkom namiesto toho, aby sme ich súdili, ignorovali, alebo podceňovali, hlavne pokial' sú nám nepríjemné. Zmienené dva komponenty sú obsiahnuté vo väčšine definícií všímavosti (Coffey, Hartman, Fredrickson, 2010).

Všímavost' má však celý rad aspektov, ktoré sú prepojené a vzájomne sa ovplyvňujú. Skupina autorov Baer, Smith, Hopkins, Krietemeyer a Toney $(2006,2008)$ definovala všímavost' prostredníctvom piatich aspektov, ktorými sú: pozorovanie vlastných zážitkov, popisovanie vlastných zážitkov, konanie na základe uvedomovania, nehodnotenie vlastných zážitkov a nereagovanie na vlastný zážitky. Pozorovanie vlastných zážitkov vyjadruje registrovanie a venovanie pozornosti vnútorným aj vonkajším vnemom, ktorými môžu byt' pocity, kognitívne schopnosti, emócie, zvuky či vône. Popisovanie vlastných zážitkov sa viaže k schopnosti previest' vlastné vnútorné zážitky do slovnej podoby. Konanie na základe uvedomovania spočíva v schopnosti vykonávat’ činnost' s plným vedomím, bez úteku myšlienok iným smerom. Zahŕňa vyvarovanie sa zautomatizovanému správaniu a mysleniu. Nehodnotenie vlastných zážitkov zahŕňa nezaujatý postoj k vlastným myšlienkam a emóciám. Nereagovanie na vlastné zážitky sa vzt'ahuje k vnútorným skúsenostiam a znamená schopnost' jednotlivca nechat' myšlienky a pocity prirodzene plynút', namiesto toho, aby sa nimi nechával príliš uniest'. V našej štúdii vychádzame práve z uvedenej koncepcie (Baer et al, 2006) zameranej na pät' aspektov všímavosti.

\subsection{Autenticita}

Význam autenticity je zdôrazňovaný mnohými autormi. Jeden z najvýstižnejších popisov autenticity (Prochaska, Norcross, 1999, s. 88) uvádza že „autentická existencia prináša otvorenost' $k$ vzt'ahu $k$ prírode, druhým a $k$ sebe samým, pretože sme sa rozhodli postavit' sa $k$ svetu čelom, neutekat' pred sebou ani pred ním". Otvorenost' znamená, že autentickí l'udia sú si d'aleko viac vedomí, pretože si vybrali, že pred ničím nebudú zatvárat' oči. Autentická existencia tiež dáva slobodu správat' sa spontánne v kontakte s druhými l'ud'mi, ked'že sa nebojíme, že by sme na seba niečo prezradili, čo je v rozpore s tým, čo sme predstierali (Prochaska, Norcross, 1999). Autenticita je popri empatii a akceptácii, jedným zo základných pilierov na klienta orientovaného prístupu v humanistickej psychológii. Jej hlavní predstavitelia, Rogers (1973) a Maslow (1954), ju popisujú ako klúčovú charakteristiku zdravého duševného života a fungujúcich vzt'ahov. Rogers (1980) vníma autenticitu ako zmysel pre posilnenie a slobodu správat' sa spôsobom, ktorý je vyjadrením hlboko zakorenených hodnôt, ciel'ov a pocitov, namiesto vnímania autenticity ako produktu externých tlakov a očakávaní. Wood a kol. (2008) sa zamerali na definíciu autenticity z pohl’adu na človeka zameraného prístupu preto, že poskytuje najširšie a najúplnejšie vysvetlenie konštruktu. Navrhli trojkomponentnú koncepciu autenticity, ktorá zahŕňa faktory sebaodcudzenia (nesúlad medzi tým, čo jedinec zažíva a aký v skutočnosti je), autentické žitie (vystupovanie v sociálnych interakciách, ktoré zodpovedajú hodnotám a presvedčeniam daného človeka) a prijímanie vonkajších vplyvov.

V súvislosti s autenticitou sa môžeme stretnút' aj s pojmom kongruencia. Mnohí autori považujú tieto dva pojmy za synonymá. Rogers (1980) v súvislosti s pojmom autenticita uvádza niekol'ko synoným ako napr. „kongruencia“, „,elistvost"“ a „integrovanost“". Šiffelová (2010) tieto pojmy neskôr doplnila o „skutočnost"“, „reálnost”“ a „transparentnost”“. Kongruencia (z lat. congrues zhodujúci sa, súhlasný, primeraný) označuje súlad - neprítomnost' rozporu medzi prejavom jednotlivca (voči okoliu aj k sebe) a jeho sebapochopením (Šiffelová, 2010; Vymětal, 2010). Gajdošová (2013) chápe autenticitu resp. kongruenciu ako komplexnú premennú odzrkadl'ujúcu zrelost' osobnosti človeka, pričom jej úroveň definuje naše psychické zdravie a je v určitom zmysle ideálom, ktorý by sme sa mohli snažit' dosiahnut'. V štúdii nadväzujeme na spomínaných autorov, ktorí považujú autenticitu a kongruenciu za synonymá, čo nám neskôr umožní použit’ na meranie 
autenticity Škálu kongruencie (Lee, 2002) a vychádzat’ z ponímania autenticity resp. kongruencie podl'a Leeovej (2002), ktorá je konceptualizovaná ako stav uvedomenia, otvorenosti a spojenia v troch dimenziách: intrapsychickej, interpersonálnej a spirituálnej. Intrapsychická dimenzia zahŕňa na rôznych úrovniach dynamiku vyskytujúcu sa vo vnútri človeka (Satir et al., 2005). Týka sa našich pocitov, ktorých sme si vedomí, uznávame a prijímame ich, pretože nám patria (Satir et al., 2005). Pri interpersonálnej dimenzii ide o spojenie medzi osobami (Lee, 2002). Predovšetkým ide o komunikáciu a o kongruentnú komunikáciu, ktorú možno opísat' ako komunikáciu zahŕňajúcu a rešpektujúcu tri aspekty komunikačného aktu - ja, druhí a kontext (Lee, 2002). L'udia, ktorí dosiahnu túto úroveň sú v súlade so sebou, s ostatnými a taktiež sú v súlade s kontextom (Satir et al., 2005). Spirituálna dimenzia sa týka harmonizovania s naším spirituálnym základom (Satir et al., 2005). Táto dimenzia je v modeli osobnosti tvorená zložkami túžby a self. Autenticita vo vzt’ahu k túžbam znamená ich znalost', uvedomenie a prijatie (Lee, 2005).

\subsection{Vzt'ah všímavosti a autenticity u adolescentov}

Autenticita je vnímaná v súvislosti s identitou človeka, v zmysle stotožnenia sa samého so sebou. V humanistickej psychológii je spojená so zmyslom života, s l'udskými hodnotami a zodpovednost'ou človeka a s tým zákonite prepojenými etickými nárokmi a výzvami (Vymětal, 2010). Preto sa v štúdii zaoberáme vzt'ahom autenticity a všímavosti u adolescentov, nakol'ko práve adolescencia je obdobím nástupu a napíňania vlastnej identity, kedy si adolescent začína uvedomovat' svoju jedinečnost’ a autenticitu (Šramová, 2006).

Pri skúmaní súvislosti medzi všímavost'ou a autenticitou môžeme vychádzat' z teoretického vymedzenia premenných, ktoré môže naznačovat' ich vzájomný prienik. Ako tvrdia Allan, Bott a Suh (2015), teória sebaurčenia (SDT) (Deci, Ryan, 1985) predstavuje teoretický základ naznačujúci, že všímavost' môže viest' k väčšej autenticite. Podl'a Browna a Ryana (2003) všímavost' charakterizovaná otvoreným, nespochybneným uvedomením prispieva k zvýšeniu autentického sebauvedomenia. Empiricky skúmali vzt'ah všímavosti a autenticity Kernis a Goldman (2006), ktorí medzi nimi zistili pozitívnu súvislost'.

Ciel'om našej štúdie je skúmat' vzt'ah medzi všímavost'ou a autenticitou u adolescentov, a to najmä z dôvodu, že podl'a Sawicki (2014) sa na Slovensku skúmaniu všímavosti venuje minimálna pozornost'. Na základe výskumu Kernisa a Goldmana (2006) môžeme predpokladat', že medzi všímavost'ou a autenticitou bude pozitívny vzt'ah aj v prípade nami zvolenej vzorky adolescentov. Ďalej nás taktiež zaujíma podrobnejšie preskúmanie daného vzt'ahu, kde budeme zist'ovat' či a ako súvisia jednotlivé aspekty všímavosti s autenticitou u adolescentov.

\section{METÓDY}

\subsection{Výskumný súbor}

Výskumný súbor pozostával zo 104 respondentov v období adolescencie (t.j. od 15 do 20 rokov; $\mathrm{M}_{\mathrm{vek}}=17,4 ; \mathrm{SD}_{\mathrm{vek}}=2,16$ ). Išlo o študentov stredných škôl z okresu Rimavská Sobota. Z celkového počtu participantov bolo dievčat 67 a chlapcov 37.

\subsection{Meracie nástroje}

Vo výskume boli použité dva meracie nástroje: Five-Facet Mindfulness Questionnaire (Baer et al, 2006) a Škála kongruencie (Lee, 2002). Oba nástroje v nasledujúcom texte stručne predstavíme.

Five-Facet Mindfulness Questionnaire (FFMQ) obsahuje 39 položiek ktoré sa vzt'ahujú k piatim aspektom všímavosti. 5 škál dotazníka meria nasledovné aspekty všímavosti (Baer et al., 2006, 2008): 
1) Pozorovanie vlastných zážitkov - vyššie skóre ukazuje na vnímavost’ alebo otvorenost' voči svetu a ochotu venovat' pozornost' svojim pocitom.

2) Popisovanie vlastných zážitkov - je schopnost'ou vyjadrit’ svoje pocity, myšlienky alebo predstavy vo forme slov.

3) Konanie na základe uvedomovania - hodnotí schopnost' byt' úplne pozorný k činnosti, ktorú človek momentálne robí - opakom je automatické správanie. L'udia s nízkym skóre sú často angažovaní v automatickom alebo neurotickom konaní a bezmyšlienkovito sa správajú tak, aby znížili svoju úzkost'.

4) Nehodnotenie vlastných zážitkov - predstavuje nehodnotiaci postoj k vlastným myšlienkam a pocitom. L’udia s vyšším skóre svoje zážitky prijímajú, a to bez toho, aby ich nutne hodnotili.

5) Nereagovanie na vlastné zážitky - vnímanie svojho vnútorného prežívania, emócií a myšlienok s odstupom; možnost' nenechat' sa vtiahnut' do automatických spôsobov reagovania na toto prežívanie

Škála kongruencie je relatívne nový merací nástroj, ktorý v Spojených Štátoch vyvinula Lee (2002). Vychádza z konceptualizácie kongruencie ako stavu vedomia a otvorenosti na troch základných úrovniach resp. dimenziách skúseností: intrapsychickej, interpersonálnej a spirituálnej (boli popísané v kap. 1.2). Dotazník obsahuje 75 položiek reprezentujúcich uvedené tri dimenzie.

\section{3 Štatistické spracovanie dát}

Štatistické spracovanie dát sme uskutočnili v programe IBM SPSS Statistics 21. Vzt'ahy medzi všímavost'ou a autenticitou sme zist'ovali prostredníctvom Spearmanovej poradovej korelácie vzhl'adom k tomu, že dáta nemali normálnu distribúciu.

\section{VÝSLEDKY}

Korelovali sme autenticitu a jej dimenzie so všímavost'ou globálnou a postupne aj so všetkými aspektmi všímavosti. Výsledky korelačných analýz uvádzame v tabul’kách.

\section{Všímavost' vo vzt'ahu $\mathrm{k}$ autenticite}

Tab 1 Vzt'ah všímavosti k autenticite (a jej dimenziám)

Všímavost'

\begin{tabular}{c|c|c}
\hline Autenticita a jej dimenzie & $\mathrm{r}_{\mathrm{s}}$ & $\mathrm{P}$ \\
\hline Autenticita (celková) & $\mathbf{0 , 4 3 6}$ & $<0,001$ \\
Intrapsychická dimenzia & $\mathbf{0 , 3 3 7}$ & $<0,001$ \\
Interpersonálna dimenzia & $\mathbf{0 , 4 2 8}$ & $<0,001$ \\
Spirituálna dimenzia & $\mathbf{0 , 3 8 8}$ & $<0,001$ \\
\hline
\end{tabular}

Legenda: rs - hodnota Spearmanovho korelačného koeficientu, $p$-štatistická signifikancia

Zistili sme, že medzi globálnou všímavost'ou a autenticitou ako celkom a tiež jej intrapsychickou, interpersonálnou a spirituálnou dimenziou sú signifikantné stredne silné pozitívne vzt’ahy $v$ rozpätí od $r_{s}=0,337$ do $r_{s}=0,436$.

\section{Aspekty všímavosti vo vzt'ahu k autenticite}


Tab 2 Vzt'ah pozorovania vlastných zážitkov k autenticite (a jej dimenziám)

Pozorovanie vlastných zážitkov

\begin{tabular}{c|c|c}
\hline Autenticita a jej dimenzie & $\mathrm{r}_{\mathrm{s}}$ & $\mathrm{p}$ \\
\hline Autenticita (celková) & $\mathbf{0 , 2 3 8}$ & 0,015 \\
Intrapsychická dimenzia & $\mathbf{0 , 2 2 7}$ & 0,021 \\
Interpersonálna dimenzia & $\mathbf{0 , 2 1 0}$ & 0,033 \\
Spirituálna dimenzia & $\mathbf{0 , 2 8 2}$ & 0,004 \\
\hline
\end{tabular}

Legenda: rs - hodnota Spearmanovho korelačného koeficientu, $p$-štatistická signifikancia

Aspekt pozorovanie vlastných zážitkov vykazoval s autenticitou a jej dimenziami signifikantné slabé pozitívne vzt'ahy $v$ rozpätí od $r_{s}=0,210$ do $r_{s}=0,282$.

Tab 3 Vzt'ah popisovania vlastných zážitkov $k$ autenticite (a jej dimenziám)

Popisovanie vlastných zážitkov

\begin{tabular}{c|c|c}
\hline Autenticita a jej dimenzie & $\mathrm{r}_{\mathrm{s}}$ & $\mathrm{p}$ \\
\hline Autenticita (celková) & $\mathbf{0 , 2 4 9}$ & 0,011 \\
Intrapsychická dimenzia & $\mathbf{0 , 2 0 4}$ & 0,038 \\
Interpersonálna dimenzia & $\mathbf{0 , 2 0 5}$ & 0,037 \\
Spirituálna dimenzia & $\mathbf{0 , 2 1 9}$ & 0,025 \\
\hline
\end{tabular}

Legenda: rs - hodnota Spearmanovho korelačného koeficientu, $p$-štatistická signifikancia

Pri aspekte popisovania vlastných zážitkov sme taktiež zistili k autenticite a jej trom dimenziám signifikantné pozitívne slabé vzt'ahy. Hodnoty korelačných koeficientov sa pohybovali v rozpätí od $r_{s}=0,204$ do $r_{s}=0,219$.

Tab 4 Vzt'ah konania na základe uvedomovania k autenticite (a jej dimenziám)

Konanie na základe uvedomovania

\begin{tabular}{c|c|c}
\hline Autenticita a jej dimenzie & $\mathrm{r}_{\mathrm{s}}$ & $\mathrm{p}$ \\
\hline Autenticita (celková) & 0,192 & 0,051 \\
Intrapsychická dimenzia & $\mathbf{0 , 2 3 3}$ & 0,018 \\
Interpersonálna dimenzia & $\mathbf{0 , 2 0 9}$ & 0,033 \\
Spirituálna dimenzia & 0,120 & 0,224 \\
\hline
\end{tabular}

Legenda: rs - hodnota Spearmanovho korelačného koeficientu, $p$-štatistická signifikancia

Ďalší aspekt všímavosti, konanie na základe uvedomovania, nevykazoval významný vzt'ah $\mathrm{k}$ autenticite ako celku. Čo sa týka dimenzií autenticity, konanie na základe uvedomovania je vo významnom vzt'ahu sintrapsychickou a interpersonálnou dimenziou. Vzt’ahy sú pozitívne a z hl'adiska sily slabé. Pri spirituálnej dimenzii autenticity sa nepreukázal významný vzt'ah s konaním na základe uvedomovania. 
Tab 5 Vzt'ah nehodnotenia vlastných zážitkov k autenticite (a jej dimenziám)

\begin{tabular}{c|c|c} 
& \multicolumn{2}{c}{ Nehodnotenie vlastných zážitkov } \\
\hline Autenticita a jej dimenzie & $\mathrm{r}_{\mathrm{s}}$ & $\mathrm{p}$ \\
\hline Autenticita (celková) & $\mathbf{0 , 2 7 7}$ & 0,004 \\
Intrapsychická dimenzia & $\mathbf{0 , 2 1 6}$ & 0,027 \\
Interpersonálna dimenzia & $\mathbf{0 , 2 3 5}$ & 0,016 \\
Spirituálna dimenzia & $\mathbf{0 , 2 9 2}$ & 0,003 \\
\hline
\end{tabular}

Legenda: rs - hodnota Spearmanovho korelačného koeficientu, $p$-štatistická signifikancia

Nehodnotenie vlastných zážitkov významne pozitívne koreluje s autenticitou a jej dimenziami, pričom vzt'ahy sú slabé v rozpätí od $r_{s}=0,216$ do $r_{s}=0,292$.

Tab 6 Vzt’ah nereagovania na vlastné zážitky $k$ autenticite (a jej dimenziám)

Nereagovanie na vlastné zážitky

\begin{tabular}{c|c|c}
\hline Autenticita a jej dimenzie & $\mathrm{r}_{\mathrm{s}}$ & $\mathrm{p}$ \\
\hline Autenticita (celková) & $\mathbf{0 , 2 8 5}$ & 0,003 \\
Intrapsychická dimenzia & $\mathbf{0 , 2 3 7}$ & 0,015 \\
Interpersonálna dimenzia & $\mathbf{0 , 2 9 1}$ & 0,003 \\
Spirituálna dimenzia & $\mathbf{0 , 2 2 9}$ & 0,020 \\
\hline
\end{tabular}

Legenda: rs - hodnota Spearmanovho korelačného koeficientu, $p$-štatistická signifikancia

Pri nereagovaní na vlastné zážitky sme zistili podobné vzt’ahy ako v predchádzajúcom prípade, teda významné pozitívne a stredne silné vzt’ahy s autenticitou a jej dimenziami.

\section{DISKUSIA}

Ciel'om predkladanej štúdie bolo skúmat' vzt'ah medzi všímavost'ou a autenticitou u adolescentov. Význam skúmania konceptu všímavosti sme videli v tom, že podl'a Sawicki (2014) sa skúmaniu tejto kompetencie na Slovensku venuje minimálna pozornost', pričom vzhl'adom na jej dôležitost' v sociálnych vzt'ahoch a duševnom zdraví by bolo prospešné sa ňou vedecky zaoberat'. Nie je nám tiež známy ani tuzemský výskum zaoberajúci sa všímavost’ou v súvislosti s autenticitou, chápanou ako poznanie a konanie v súlade so svojim skutočným self (Allan, Bott Suh, 2015). Vzt'ah konceptu všímavosti a autenticity u adolescentov sa tak stal predmetom nášho skúmania. Pre lepšie pochopenie súvislosti medzi konceptom všímavosti a autenticitou sme sa rozhodli skúmat' vo vzt’ahu k autenticite a jej dimenziám nie len všímavost' globálnu, ale aj jej jednotlivé aspekty pozorovanie vlastných zážitkov, popisovanie vlastných zážitkov, nehodnotenie vlastných zážitkov, nereagovanie na vlastné zážitky.

V prípade globálnej všímavosti sme zistili stredne silné pozitívne vzt’ahy k autenticite a všetkým trom jej dimenziám u adolescentov. Výsledky zodpovedajú nášmu predpokladu aj empirickým zisteniam Kernisa a Goldmana (2006), i ked' autori získali o niečo silnejšie vzt’ahy autenticity so všímavost'ou meranou dvomi nástrojmi ( $\mathrm{r}=0,49 ; \mathrm{r}=0,64)$. Pozitívnu koreláciu medzi všímavost'ou a autenticitou zistili tiež Leroy et al. (2013). Naše výsledky sú teda konzistentné so zmienenými 
empirickými zisteniami aj tvrdeniami autorov ako napr. Allan, Bott, Suh (2015), podl'a ktorých všímavost' môže ul'ahčit' sebapochopenie ako jednu zo zložiek autentického fungovania. Brown a Ryan (2003) popisujú, že všímavost' súvisí s autentickým fungovaním tým spôsobom, že vnímavé vnútorné povedomie o svojich myšlienkach, emóciách a správaní pomáha jednotlivcovi viac si uvedomit' svoje skutočné self.

Ked' sa presunieme k jednotlivým aspektom všímavosti, zist'ujeme, že prvý aspekt všímavosti, a to pozorovanie vlastných zážitkov pozitívne koreluje s autenticitou a jej jednotlivými dimenziami. Aspekt pozorovania vlastných zážitkov je spojený s registrovaním a venovaním pozornosti vnútorným aj vonkajším zážitkom, akými sú pocity, kognície, emócie, zvuky, vône a pod. (Baer et al., 2008). Môžeme sa domnievat', že ak človek svoje zážitky, pocity, emócie dokáže registrovat' a vnímat', môže si ich aj lepšie uvedomovat', pričom vychádzame z tvrdenia Deciho a Ryana (1985) ktorí konštatujú, že všímavost' môže viest' l'udí k tomu, aby si viac uvedomovali svoje myšlienky, pocity a skúsenosti, ktoré by im mohli pomôct' uvedomit' si aj ich osobné autentické hodnoty a presvedčenia. Aj podl'a Satirovej (2005) s uvedomovaním a prijímaním vlastných pocitov súvisí úroveň autenticity. Čím viac je teda človek pozorný k vlastným zážitkom, tým môže podl'a našich výsledkov dosahovat' väčšiu mieru autenticity na úrovni intrapersonálnej, intrapsychickej aj spirituálnej. Zároveň však netreba zabúdat’ na interpersonálnu úroveň, ktorá podl’a Kusého (2015) môže odzrkadl'ovat' prostredníctvom jednotlivých behaviorálnych vzorcov individuálnu psychodynamiku v interakcii s okolím v interpersonálnom priestore.

Treba však podotknút', že zistené vzt'ahy aspektu pozorovania vlastných zážitkov s autenticitou sú z hl'adiska ich sily pomerne slabé. Slabý vzt’ah medzi autenticitu a pozorovaním ako aspektom všímavosti však zistili aj Kernis a Goldman (2006)

Pri druhom aspekte všímavosti, popisovaní vlastných zážitkov, sme taktiež zistili pozitívnu súvislost' s autenticitou aj jej tromi dimenziami. Adolescenti, ktorí dosahovali vyššie skóre v aspekte popisovania vlastných zážitkov, ktorý predstavuje schopnost' previest' vlastné vnútorné zážitky do slovnej podoby (Baer et al.,2008), dosahovali aj vyššie skóre v úrovni autenticity. Aj pri tomto aspekte autenticity môžeme uvažovat' nad tým, že ak adolescenti dokážu verbalizovat' svoje myšlienky, pocity a predstavy, tento proces im môže napomôct' aj k ich uvedomeniu, ktoré môže súvisiet' s autenticitou, čo podporujú aj tvrdenia vyššie spomenutých autorov (Kernis, Goldmann, 2006; Satir et al., 2005).

Konanie na základe uvedomovania ako jediný aspekt všímavosti nekoreloval s autenticitou. Čo sa týka dimenzií autenticity, konanie na základe uvedomovania bolo v slabom pozitívnom vzt'ahu $\mathrm{k}$ intrapsychickej a interpersonálnej dimenzii a nevykazovalo vzt’ah k spirituálnej dimenzii. Nepreukázaný vzt'ah konania na základe uvedomovania a autenticity je v rozpore so zisteniami Kernisa a Goldmanna (2006), ktorý medzi premennými stredne silný vzt'ah zistili. Podl'a autorov sa vedomé konanie vzt'ahuje k autentickým hodnotám, potrebám a želaniam človeka. Uvedomenie si vlastného konania umožňuje, aby človek konal autenticky a nie na základe želaní a prosieb ostatných. Náš výsledok pre aspekt konanie na základe uvedomovania nekonzistentný s výskumom Kernisa a Goldmanna (2006) by mohol pramenit’ z toho, že autori pri svojom výskume vychádzajú z inej, štvorkomponentovej koncepcie všímavosti, na rozdiel od nás.

Ďalším skúmaným aspektom všímavosti bolo nehodnotenie vlastných zážitkov, pri ktorom sme zistili slabé pozitívne vzt'ahy s autenticitou a jej dimenziami. Naše výsledky by mohli naznačovat', že adolescenti, ktorí prijímajú svoje zážitky bez toho, aby ich nutne hodnotili dokážu lepšie dosiahnut' stav celistvosti a vnútornej centrovanosti, kedy sú v súlade so sebou, s ostatnými a vo vzt'ahu s kontextom, teda stav charakterizujúci autenticitu (Satir et al., 2005), i ked' si uvedomujeme, že zistený vzt'ah bol slabý. Jeho pozitívny smer však môže prispievat' k podpore vyjadrení autorov (napr. Carlsonová, 2013) o tom, že všímavost' vd'aka nehodnoteniu môže 
odstránit' motivačné bariéry brániace sebapoznaniu, nakol'ko iracionálne správanie môže byt' motivované aj snahou vyhnút' sa negatívnemu sebaobrazu stratou sebaúcty. Podl'a Kernisa a Goldmana (2006) neskreslené spracovávanie informácií o sebe zahŕňa objektívne rozpoznanie pozitívnych, ale i negatívnych aspektov vlastnej osobnosti. Práve ako poznanie a konanie v súlade so svojou osobnost'ou, so svojim skutočným self je definovaná autenticita (Allan, Bott, Suh, 2015).

Pri poslednom aspekte všímavosti, ktorým je nereagovanie na vlastné zážitky, sme zistili s autenticitou a jej dimenziami podobné vzt’ahy ako v prípade predošlého aspektu všímavosti. Zistená pozitívna, i ked' slabá súvislost' naznačuje, že vyššia schopnost' adolescentov vnímat' svoje vnútorné zážitky, emócie a myšlienky s odstupom a nenechat’ sa uniest' alebo zapliest' do myšlienok a emócií sa môže odrazit’ aj vyššou autenticitou. V súlade s tým Possehl a Kittel (2008) tvrdia, že neautentické a strnulé vzorce správania vznikajú stratou odstupu a ponorením sa do minulých myšlienok a emócií. Podl'a Frančeho (2018) zas autentické správanie umožňuje získat' odstup a oslobodit' sa od v minulosti prežitých negatívnych a úzkostných vzorcov správania.

Uvedomujeme si, že nami zistené vzt'ahy aspektov všímavosti k autenticite a jej dimenziám boli slabé, pričom Kernis a Goldman (2006) sa vo svojom výskume dopracovali aj k silnejším koreláciám. Uvažujeme, že uvedené by mohlo súvisiet’ s použitými nástrojmi. FFMQ k meraniu všímavosti bol adaptovaný na slovenskú populáciu a jeho psychometrické vlastnosti boli zist'ované rôznymi spôsobmi (Látalová, Pilárik, 2014). V tomto ohl'ade by si škála k meraniu autenticity vyžadovala podobne dôkladný proces, čo považujeme za limit štúdie, pričom odporúčame v budúcnosti prihliadat' aj na kultúrne špecifiká konštruktu, nakol'ko nástroj pochádza z iného kultúrneho prostredia. Ako d’alší limit tiež vnímame sebavýpoved'ový charakter metódy k meraniu autenticity. V štúdii sme sa zamerali na adolescentov, a teda vyvstáva otázka, nakol'ko sú adolescenti schopní adekvátneho sebaposúdenia v tejto vlastnosti. Za limit tiež považujeme nevyvážený pomer dievčat a chlapcov vo výskumnom súbore a pri d’alšom skúmaní odporúčame preto vyrovnanejší súbor z hl'adiska pohlavia.

\section{ZÁVER}

Štúdia sa zaoberala vzt’ahom všímavosti a autenticity u adolescentov. Skúmali sme nielen globálnu všímavost', ale aj jej aspekty v súvislosti s autenticitou a jej intrapsychickou, intrapersonálnou a spirituálnou dimenziou. Z výsledkov vyplýva, že najsilnejšie vzt’ahy (stredne silné) sme zistili pri skúmaní globálnej všímavosti vo vzt’ahu k autenticite ako celku a jej trom dimenziám. Na úrovni jednotlivých aspektov všímavosti sme zistili len slabé vzt’ahy a aspekt konania na základe uvedomovania nesúvisel s celkovou autenticitou ani s jej spirituálnou dimenziou. Štúdiou sme prispeli k poznaniu problematiky všímavosti, ktorá je na Slovensku pomerne opomínaná a tiež sme sa pokúsili objasnit' vzt'ah konceptu všímavosti kautenticite a to na špecifickej vzorke adolescentov. Autenticita je vnímaná v súvislosti s identitou človeka (Vymětal, 2010) a práve tá je dôležitou témou v období adolescencie.

\section{LITERATÚRA}

Allan, B. A., Bott, E. M., \& Suh, H. (2015). Connecting Mindfulness and Meaning in Life: Exploring the Role of Authenticity. Mindfulness, 6(5), 996-1003.

Baer, R. A., Smith, G. T., Hopkins, J., Krietemeyer, J., \& Toney, L. (2006). Five Facet Mindfulness Questionnaire. University of Kentucky, Lexington, Kentucky.

Baer, R. A., Smith, G. T., Lykins, E., Button, D., Krietemeyer, J., Sauer, S., ... \& Williams, J. M. G. (2008). Construct validity of the five facet mindfulness questionnaire in meditating and nonmeditating samples. Assessment, 15(3), 329-342. 
Benda, J. (2007). Všímavost v psychologickém výzkumu a v klinické praxi. Československá psychologie, 51(2), 129 - 140.

Brown, K. W., \& Ryan, R. M. (2003). The benefits of being present: Mindfulness and its role in psychological well-being. Journal of Personality and Social Psychology, 84(4), 822-848.

Brown, K. W., Ryan, R. M., \& Creswell, J. D. (2007). Mindfulness: Theoretical foundations and evidence for its salutary effects. Psychological Inquiry, 18(4), 211-237.

Carlson, E. N. (2013). Overcoming the Barriers to Self- Knowledge: Mindfulness as a Path to Seeing Yourself as You Really Are. Perspectives on Psychological Science, 8(2), 173-186.

Coffey, K. A., Hartman, M., \& Fredrickson, B. L. (2010). Deconstructing mindfulness and constructing mental health: Understanding mindfulness and its mechanisms of action. Mindfulness, 1(4), 235-253.

Deci, E. L., \& Ryan, R. M. (1985). The general causality orientations scale: Self-determination in personality. Journal of research in personality, 19(2), 109-134.

Franče, V. (2018). Komunikační typy. Retrieved from http://ografologii.blogspot.com/2007/11/komunikacni-typy.html>.

Gajdošová, B. (2013). Prístup zameraný na človeka. Košice: Univerzita Pavla Jozefa Šafárika.

Jurkovič, M. (2015). Miera črtovej všímavosti vo vzt’ahu ku kognitívnym zaujatostiam. In I. Farkaš, M. Tkáč, J. Rybár, J. Kelemen (Eds.), Kognícia a umelý život (1. ed., pp. 67-73). Bratislava: Univerzita Komenského v Bratislave.

Kabat-Zinn, J. (2003). Mindfulness-based interventions in context: past, present, and future. Clinical psychology: Science and practice, 10(2), 144-156.

Kernis, M.H., \& Goldman, B.M. (2006). A multicomponent conceptualization of authenticity: Theory and research. Advances in experimental social psychology, 38, 283-357.

Koróniová, J. (2016). Kvalitatívna analýza efektu tréningu všímavosti na úroveň sebakritickosti a sebasúcitu. In M. Tvrdoň, P. Pellešová, M. Šeligová, L.W. Zotyková, H. Hráčková, M. Snopoková (Eds.), IX. Medzinárodní vědecká konference doktorandů a mladých vědeckých pracovníkủ: Sborník př́spěvkư. (1.ed., pp. 113-125). Opava: Slezská univerzita v Opavě.

Kusý, P. (2015). Interpersonálne tendencie ako odraz individuálnej psychodynamiky v skupine. Emental: elektronický časopis o mentálnom zdraví. 3 (2). 6-12.

Látalová, V., \& Pilárik, L. (2014). Overenie psychometrických vlastností a faktorovej štruktúry slovenskej verzie dotazníka FFMQ (five-facet mindfulness questionnaire). Psychologie a její kontexty, 5(2), 81-99.

Lee, B. K. (2002). Development of a Congruence Scale based on the Satir Model. Contemporary Family Therapy, 24(1), 217-239.

Leroy, H., Anseel, F., Dimitrova, N. G., \& Sels, L. (2013). Mindfulness, authentic functioning, and work engagement: a growth modeling pproach. Journal of Vocational Behavior, 82(3), 238-247

Linley, P.A., Joseph, S., Harrington S., \& Wood, A.M. (2006). Positive psychology: Past, present, and (possible) future. The Journal of Positive Psychology, 1(1), 3-16.

Maslow, A. H. (1954). Motivation and personality. New York: Harper Collins. 
Penman, D., \& Vidyamala, B. (2016). Meditace pro zdraví: Praktický průvodce pro zvládání bolesti, nemocí a stresu pomocí všímavosti. Praha: Grada.

Possehl, G., \& Kittel, F. (2008). Jak se prosadit a přesvědčit ostatní. Praha: Grada.

Prochaska, J.O., \& Nocross, J.C. (1999). Psychoterapeutické systémy: průřez teoriemi. Praha: Grada.

Rogers, C. R. (1973). Client-centered therapy: its current practise, implications and theory. London: Constable.

Rogers, C. R. (1980). A way of being. New York: Houghton Mifflin Company.

Satir, V., Banmen, J., Greber, J., \& Gomori, M. (2005). Model růstu: za hranice rodinné terapie. Brno: Cesta.

Sawicki, S. (2014). Pohybové aktivity a všímavost' u mladých l'udí. Pedagogika, 5(4), 290-302.

Sheldon, K. M. (2004). Integrity (honesty/authenticity). In C. Peterson \& M. E. P. Seligman (Eds.), Character strengths and virtues (pp. 249 - 272). New York: Oxford University Press.

Šiffelová, D. (2010). Rogersovská psychoterapie pro 21. století. Praha: Grada.

Šramová, B. (2006). Štýly identity adolescentov a výchovný štýl v rodine. Psychológia a patopsychológia diet'at'a, 42(1), 3-14.

Vymětal, J. (2010). Úvod do psychoterapie. Praha: Grada.

Wood, A. M., Linley, P. A., Maltby, J., Baliousis, M., \& Joseph, S. (2008). The authentic personality: a theoretical and empirical conceptualization and the development of the Authenticity Scale. Journal of Counseling Psychology,55(3), 385-399.

\section{MINDFULNESS AND AUTHENTICITY IN ADOLESCENTS}

Abstract: The aim of the study was the examination of relationship between mindfulness and authenticity in adolescents. The research sample consisted of 104 participants (67 girls, 37 boys) with average age $\mathrm{M}_{\text {age }}=17.4 \quad\left(\mathrm{SD}_{\mathrm{age}}=2.16\right)$. The following questionnaires were used: Five-Facet Mindfulness Questionnaire - FFMQ (Baer et al, 2006) and Congruence Scale (Lee, 2002). The results point out that there are moderate positive relations between global mindfulness and authenticity (as well as its individual dimensions).We also found out poor positive relationships between aspects of mindfulness and authenticity.

Key words: mindfulness, authenticity, adolescents 